\title{
Changing the Face of the Construction Industry
}

\section{Donna De Carolis (Drexel University)}

\section{KEYWORDS: Management of Companies \&}

Enterprises, Construction, Leadership, Family Business, Women.

The construction industry remains stubbornly a maledominated field, but Emily Bittenbender of Bittenbender Construction is giving it a new face and a new approach to managing. At age 29 she was capital programs director for the City of Philadelphia, managing 100 unionized workers and $\$ 3.2$ billion in accounts. Twelve years ago she liquidated all her assets to create her own company and a work environment that felt like a family. Today Bittenbender Construction is thriving, and powered by a flat, collaborative organization that handles the inevitable pressure with humor and an ability to switch gears with ease. In this interview with Donna DeCarolis, dean of the Charles Close School of Entrepreneurs at Drexel University, Bittenbender shares her insights about what makes women effective leaders, especially in a man's world.

\section{Read More:}

Advice, Best Practices and Inspiration for Women Entrepreneurs(https://familybusiness.org/women)

Additional search terms: women, feminism, female founders, women business owners, glass ceiling, opportunity 